\title{
KETIDAK LENGKAPAN DOKUMEN REKAM MEDIS RAWAT INAP PADA PASIEN DIABETES MELLITUS DI RSU IMELDA MEDAN
}

\author{
1. Ali Sabela hasibuan; ${ }^{2}$ Giovani Malau \\ ${ }^{1 .}$ Dosen DIII Perekam dan Infokes Imelda, Jalan Bilal Nomor 52 Medan; \\ 2.Alumni DIII Perekam dan Infokes Imelda Jalan Bilal Nomor 52 Medan \\ E-mail: ${ }^{1 .}$ alisabelahasibuan@gmail.com \\ 2. giovanimalau@gmail.com
}

\begin{abstract}
ABSTRAK
Penelitian ini bertujuan untuk mengetahui Untuk mengetahui angka ketidaklengkapan rekam medis rawat inap pasien Diabetes Mellitus di Rumah Sakit Imelda Medan. Penelitian ini menggunakan metode deskriptif yaitu suatu metode penelitian yang dilakukan dengan tujuan utama untuk mengetahui angka ketidaklengkapan pengisian rekam medis rawat inap pasien Diabetes Melitus. Dari hasil penelitian ditemukan angka ketidaklengkapan pengisian formulir catatan terintegrasi ditemukan $17.40 \%$, pengkajian awal 15, $22 \%$ resume medis terdapat $9.79 \%$ dan informed consent $17.40 \%$, nama dokter sebanyak $21.74 \%$ dan tanda tangan dokter $8.70 \%$, sedangkan untuk identifikasi pasien, catatan anastesi dan laporan operasi diisi lengkap. Adapun saran dari penulis adalah : (1) prosedur tetap Analisa Ketidaklengkapan Pengisian Rekam Medis Rawat Inap perlu direvisi agar semua formulir yang dianalisa, dan perlu dilakukan sosialisasi terus menerus.
\end{abstract}

Kata Kunci : Berkas Rekam Medis rawat inap, ketidaklengkapan

\section{PENDAHULUAN}

Perkembangan zaman yang semakin pesat membuat kebutuhan akan informasi semakin meningkat, masyarakat makin kritis akan apa yang terjadi pada dirinya, begitupun kebutuhan akan informasi kesehatan, yang kini dijadikan sebagai salah satu upaya peningkatan mutu kesehatan telah tertuang dalam Permenkes RI No. 269/Menkes/Per/III/2008 tentang Rekam Medis dalam pertimbangannya : "bahwa peningkatan mutu pelayanan kesehatan harus disertai adanya sarana penunjang yang memadai antara lain memulai penyelenggaraan rekam medis pada setiap sarana pelayanan kesehatan".

Berkas rekam medis merupakan salah satu sarana untuk menilai mutu dari rumah sakit yang berkaitan dengan pemenuhan pelayanan kesehatan yang dibutuhkan oleh masyarakat. Berdasarkan Permenkes no. 269 tahun 2008, rekam medis adalah berkas yang berisikan catatan dan dokumen tentang identitas pasien, pemeriksaan, pengobatan, tindakan, pelayanan lain yang telah diberikan kepada pasien. Dokumen rekam medis merupakan dokumen yang penting dalam proses pelayanan kesehatan, melihat dokumen rekam medis merupakan alat untuk mendeskripsikan data atau informasi kesehatan pada saat proses pelayanan. Namun, banyak pihak yang masih menganggap dokumen rekam medis tidak begitu penting, sehingga pada saat proses pengisian dokumen rekam medis sering kali tidak lengkap.

Kelengkapan dokumen rekam medis merupakan hal yang sangat penting karena berpengaruh terhadap proses pelayanan yang dilakukan oleh petugas medis dan mempengaruhi kualitas dari pelayanan suatu pukesmas atau rumah sakit. Saat ini rumah sakit dan tenaga kesehatan rawan akan 
tuntutan-tuntutan, yaitu tuntutan mutu pelayanan, tuntutan hukum dari pasien dan banyaknya pesaing dibidang yang sama. Oleh sebab itu diperlukan upaya perbaikan mutu dan menjaga mutu. Salah satu parameter untuk menentukan mutu pelayanan kesehatan di puskesmas dan rumah sakit adalah data atau informasi dari rekam medis yang baik dan lengkap. Indikator mutu rekam medis yang baik dan lengkap adalah kelengkapan isi, akurat, tepat waktu dan pemenuhan aspek persyaratan hukum.

Analisa ketidaklengkapan pengisian dokumen rekam medis ini sangat diperlukan, guna mengetahui seberapa besar angka ketidaklengkapan pengisian pada dokumen rekam medis melebihi batas waktu yang sudah diberikan, mengingat pentingnya dokumen rekam medis untuk menghasilkan informasi yang berkesinambungan. Analisa ketidaklengkapan pengisian dokumen rekam medis merupakan salah satu cara untuk menilai bagaimana mutu pelayanan pada rumah sakit yang bersangkutan. Semakin sedikit angka ketidaklengkapannya maka akan semakin bagus mutu pelayanannya

Ketidaklengkapan dalam pengisian dokumen rekam medis dapat disebabkan oleh beberapa faktor, baik faktor internal maupun faktor eksternal. Ketidaklengkapan dalam proses pengisian rekam medis dapat menyebabkan turunnya mutu pelayanan di Rumah Sakit Imelda Medan maupun akan masalah apabila nantinya dokumen rekam medis tersebut dibawa pada masalah hukum karena dokumen rekam medis yang tidak lengkap dapat menyebabkan ketidakvalitan data pada saat dibawa ke meja hukum. Oleh sebab , penulis tertarik untuk mengambil judul karya tulis imiah Ketidaklengkapan Rekam Medis Rawat Inap Pasien Diabetes Mellitus Pada Rumah Sakit Imelda Medan Tahun 2019 “

\section{Perumusan Masalah}

Berdasarkan latar belakang diatas, maka peneliti merumuskan masalah dalam penelitian yaitu "Bagaimana standar prosedur analisa ketidaklengkapan rekam medis rawat inap di RSU Imelda?',

\section{Tujuan Penelitian}

Untuk mengetahui angka ketidaklengkapan rekam medis rawat inap pasien Diabetes Melitus di Rumah Sakit Imelda Medan.

\section{Manfaat Penelitian}

1. Bagi Rumah Sakit

Dengan hasil penelitian ini diharapkan dapat menjadi bahan evaluasi dan masukan bagi pihak Rumah Sakit Imelda Medan dalam meningkatkan mutu dari rekam medis.

2. Bagi Intitusi Pendidikan

Dengan penelitian ini, peneliti dapat ikut serta dalam menambah referensi perpustakaan STIkes Imelda Medan sebagi acuan bagi peneliti sejenis berikutnya.

3. Bagi penulis

Dengan penelitian ini diharapkan dapat menambah ilmu, wawasan dan pengalaman serta sebagai sarana untuk menerapkan ilmu yang diperoleh selama kuliah dengan yang ada dilapangan khusunya dalam bidang analisa ketidaklengkapan rekam medis.

\section{METODE}

\section{Jenis Penelitian}

Jenis Penelitian yang digunakan dengan cara Analisa Deskriktif. Penelitian deskriptif adalah suatu metode dalam meneliti setatus sekelompok manusia, suatu obyek, suatu kondisi, suatu system pemikiran, ataupun suatu kelas peristiwa pada masa sekarang.

\section{Waktu Penelitian}

Dilaksanakan pada bulan April sampai Mei tahun 2019.

\section{Tempat Penelitian}

Penelitan dilakukan di RSU Imelda Pekerjaan Indonesia Medan Tahun 2019.

\section{Populasi}

Populasi adalah keseluruhan subjek penelitian(Arikunto, 2010). Populasi yang digunakan dalam penelitian ini adalah semua seluruh rekam medis rawat inap pasien 
Diabetes Melitus yang keluar/pulang bulan April Tahun 2019.

\section{Sampel}

Sampel adalah sebagian atau wakil popolasi yang diteliti (Arikunto,2010). Sampel yang digunakan dalam penelitian ini adalah seluruh populasi dijadikan sampel penelitian semuanya. Sampel yang diambil dari penelitian ini adalah 92 rekam medis.

\section{Teknik Sampling}

Teknik pengambilan sampel dalam penelitian ini adalah total sampling. Total sampling adalah teknik pengambilan sampel dimana jumlah sampel sama dengan populasi (Sugiyono 2007).

\section{Teknik Pengumpulan Data}

Peneliti membuat pengumpulan data menggunakan observasi atau pengamatan yaitu melakukan pengamatan atau observasi langsung terhadap subjek peneliti (Saryono, 2013). Cara pengumpulan data dilakukan dengan cara Observasi, yaitu dengan cara pengamatan lansung objek yang diteliti

\section{Defenisi Operasional}

Defenisi Operasional adalah untuk membatasi ruang lingkup atau pengertian variable - variable diamati/diteliti yang bermanfaat untuk mengarahkan kepada pengukuran atau pengamatan terhadap variabel - variabel yang bersangkutasn serta pengembangan instrumen (alat ukur) (Notoatmodjo, 2012).

1. Identifikasi pasien: data data mengenai keterangan pribadi pasien yang meliputi nama, tempat tanggal lahir, nomor rekam medis, yang harus ada disetiap formulir.
2. Analisa laporan umum adalah kelengkapan pengisian lembar catatan terintegrasi, resume medis, pengkajian awal medis.

3. Analisa Laporan khusus adalah kelengkapan pengisian laporan operasi, anasthesi dan hasil-hasil pemeriksaan laboratorium.

4. Review Autentifikasi adalah nama lengkap serta tanda tangan dari dokter.

5. Prosedur adalah aturan interen rumah sakit dalam melaksanakan analisa rekam medis.

\section{Instrumen}

Instrumen yang digunakan dalam penelitian adalah dengan menggunakan Pedoman Observasi dan Check list.

\section{HASIL}

Tabel 1. Persentase ketidaklengkapan pengisian identifikasi pasien pada formulir rekam medis rawat inap pasien Diabetes Mellitus di Rumah Sakit Imelda Medan Bulan Mei Tahun 2019

\begin{tabular}{llcccc}
\hline No & $\begin{array}{c}\text { Item yang di } \\
\text { analisa }\end{array}$ & \multicolumn{2}{c}{ Ada } & Tidak \\
\cline { 2 - 5 } & Jumlah & \% & Jumlah & \% \\
\hline 1 & Nama & 92 & $100 \%$ & - & - \\
\hline 2 & No RM & 92 & $100 \%$ & - & - \\
\hline 3 & Tanggal Lahir & 92 & $100 \%$ & - & - \\
\hline \multicolumn{5}{c}{ Dari tabel 1 dapat dilihat bahwa untuk } \\
identifikasi pasien disetiap lembar formulir \\
rekam medis diisi 100 lengkap. Sesuai \\
dengan hasil observasi penulis menemukan \\
untuk identifikasi pasien petugas di ruang \\
perawatan tinggal menempelkan barkode \\
yang telah disiapkan saat pasien mendaftar \\
untuk dirawat inap.
\end{tabular}

Tabel 2. Persentase ketidaklengkapan review pelaporan pada formulir rekam medis rawat inap pasien Diabetes Mellitus di Rumah Sakit Imelda Bulan Mei Tahun 2019

\begin{tabular}{clcccc}
\hline & & \multicolumn{2}{c}{ Lengkap } & \multicolumn{2}{c}{ Tidak } \\
\cline { 3 - 6 } No & \multicolumn{1}{c}{ Identifikasi } & Jumlah & \% & Jumlah & \% \\
\hline I & Laporan umum & & & & \\
\hline & Catatan terintegrasi & 76 & 82.60 & 16 & 17.40 \\
\hline & Pengkajian awal & 78 & 84.78 & 14 & 15.22 \\
\hline & Resume Medis & 83 & 90.21 & 9 & 9.79 \\
\hline II & Laporan Khusus & & & & \\
\hline & Laporan Anastesi & 92 & 100 & - & - \\
\hline & Laporan Operasi & 92 & 100 & - & - \\
\hline & Informed Conseco & 76 & 82.60 & 16 & 17.40 \\
\hline & & & & &
\end{tabular}


Dari tabel 2 dapat dilihat bahwa masih ada formulir yang tidak diisi lengkap, untuk catatan terintegrasi ditemukan $17.40 \%$ yang tidak diisi lengkap, pengkajian awal 15, 22 $\%$ yang tidak diisi lengkap, sedangkan untuk resume medis terdapat $9.79 \%$ yang tidak lengkap, untntuk formulir informed consent masih ditemukan angka ketidaklengkapan $17.40 \%$. khusus laporan anastesi dan operasi diisi dengan lengkap. Dari hasil observasi pada catatan terintegrasi masih ditemukan lembaran formulir yang kosong dan langsung disambung dengan formulir yang baru dan lembar yang kosong tersebut tidak digaris.

Tabel 3. Persentase ketidaklengkapan pengisian Autentifikasi pada formulir rekam medis rawat inap pasien Diabetes Mellitus di Rumah Sakit Imelda Bulan Mei Tahun 2019

\begin{tabular}{lllllc}
\hline & & \multicolumn{2}{c}{ Ada } & \multicolumn{2}{c}{ Tidak } \\
\cline { 3 - 6 } No & $\begin{array}{l}\text { Item yang } \\
\text { di analisa }\end{array}$ & Jumlah & \% & Jumlah & \% \\
\hline 1 & $\begin{array}{l}\text { Nama lengkap } \\
\text { dokter }\end{array}$ & 72 & $78.26 \%$ & 20 & 21.74 \\
\hline 2 & $\begin{array}{l}\text { Tanda Tangan } \\
\text { dokter }\end{array}$ & 84 & $91.30 \%$ & 8 & 8.70 \\
\hline
\end{tabular}

Dari tabel diatas dapat kita ketahui bahwa untuk autentifikasi masih ditemukan yang tidak lengkap, untuk nama dokter sebanyak $21.74 \%$ dan tanda tangan dokter $8.70 \%$. Dari hasil observasi untuk nama dokter yang tidak diisi lengkap pada umumnya di catatan terintegrasi, pada umumnya hanya menulis nama pendek saja, tidak ditulis nama lengkap dan gelar.

\section{PEMBAHASAN}

\section{Prosedur Analisa Ketidak Lengkapan Pengisian Rekam Medis Rawat Inap}

Pada dasarnya standar prosedur untuk analisa ketidaklengkapan pengisian rekam medis rawat inap sudah baik, akan tetapi untuk identifikasi pasien hanya menganalisa nomor rekam medis saja, sementara sesuai dengan aturan identifikasi pasien minimal harus ada 3 item yang harus ada yaitu : nomor rekam medis, nama dan tanggal lahir, tujuannya agar tidak terjadi kesalahan dalam mengidentifikasi pasien.

\section{Analisa Identifikasi Pasien}

Dari hasil penelitian untuk indentifikasi pasien disetiap lembran formulir sudah 100 $\%$ lengkap, karena perawat atau pun petugas di ruang rawat inap tidak perlu repot menulis lagi, cukup dengan menempelkan barkode iendifikasi pasien yang sudah disiapkan saat pasien mendaftar dibagian pendaftaran pasien rawat inap, apabila barkode kurang petugas ruangan cukup dating ke bagian pendaftarn di unit Gawat Darurat untuk dicetak ulang.

\section{Analisa Laporan}

Untuk analisa pelaporan masih ditemukan formulir yang tidak diisi lengkap, khusus nya di bagian formulir pengkajian awal medis rawat inap, catatan terintegrasi dan resume medis. Sesuai dengan peraturan yang berlaku dokumen rekam medis pasien rawat inap harus di isi lengkap 1 X 24 Jam setelah pasien pulang. Apabila rekam medis tidak diisi dengan lengkap maka akan menyebabkan mutu dari rekam medis akan berkurang, dan menyebabkan informasi yang dihasilkan tidak tepat dan akurat.

\section{Analisa Autentifikasi}

Masih ditemukannya ketidaklengkapan penulisan nama dokter serta tanda tangan pada formulir rekam medis, pada umumnya ditemukan pada formulir catatan terintegrasi. Dalam autentifikasi tidak boleh tanda tangani oleh orang lain selain dari penulisnya, kecuali bila ditulis oleh dokter jaga atau mahasiswa maka ada tanda tangan sipenulis di tambah countersign oleh supervisor dan ditulis telah direview dan dilaksanakan atas intruksi dari ... atau telah diperiksa oleh... atau diketahui oleh

\section{KESIMPULAN}

1. Untuk Standar Prosedur Operasional analisa ketidak lengkapan rekam medis rawat inap sudah berjalan dengan baik, akan tetapi untuk analisa identifikasi 
2. pasien yang dianalisa hanya nomor rekam medis saja.

3. Analisa identifikasi pasien $100 \%$ terisi lengkap.

4. Analisa laporan ditemukan angka ketidaklengkapan catatan terintegrasi ditemukan $17.40 \%$, pengkajian awal 15 , $22 \%$ resume medis terdapat $9.79 \%$ dan informed consent $17.40 \%$, sedangkan untuk catatan anastesi dan laporan operasi diisi lengkap.

5. Analisa autentifikasi masih ditemukan yang tidak lengkap, untuk nama dokter sebanyak $21.74 \%$ dan tanda tangan dokter $8.70 \%$.

\section{DAFTAR PUSTAKA}

Departemen Kesehatan RI. Direktorat Pelayanan Medik. (1997). Pedoman Pengelolaan Rekam Medis Rumah Sakit Di Indonesia. Revisi I. Jakarta: Depkes.

Direktorat Jenderal Pelayanan Medik. (2006). Pedoman Penyelenggaraan dan Proseedur Rekam Medis Rumah Sakit. Jakarta: Departemen Kesehatan RI
Hatta, G. (2008). Pedoman Manajemen Informasi Kesehatan Di Sarana Pelayanan Kesehatan. Jakarta: UIPress.

Huffman, E.K. (1994). Health Information Management. Edisi 10. Millionis; Physician Record Company.

Notoatmojo, S. (2010). Metodologi Penelitian Kesehatan. Jakarta: Rineka Cipta.

Per Menkes RI. (2008). Permenkes RI.Nomor 269/MENKES/PER/III/2008 Tentang Rekam Medis. Jakarta: Depkes RI.

Notoatmojo,Soekidjo. (2012). Metode Penelitian Kesehatan. Jakarta: Rineka Cipta.

Notoatmojo,Soekidjo. (2005). Metode penelitian.

Rustiyanto, Ery. (2010). Statistik Rumah Sakit Untuk Pengambilan Keputusan. Jakarta: Graha Ilmu.

Rustiyanto, Ery. (2009). Etika Profesi. Yogyakarta: Graha Ilmu.

Singarimbun, Masri dan Effendi Sofian. (2000). Metode Penelitian Suevei. Jakarta: Pustaka LP3 ES. 